\title{
The effects of using games on teaching vocabulary in reading comprehension: a case of gifted students
}

\author{
Aminuddin Hashemi ${ }^{1}$ \\ English Department, School of Language and Literature, Takhar University, Taloqan, Takhar, Afghanistan
}

\section{Article Info}

Received: 27 December 2020

Revised: 06 February 2021

Accepted: 10 March 2021

Available online: 15 June 2021

Keywords:

Effects of Using Games

Reading Comprehension

Vocabulary Teaching

Gifted Students

Motivation

2149-360X/ C 2021 The Authors. Published by Young Wise Pub. Ltd. This is an open-access article under the CC BY-NC-ND license

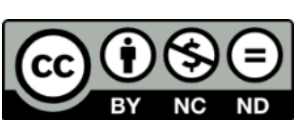

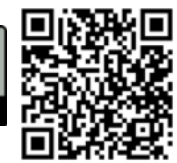

\begin{abstract}
Using educational games for the improvement of the students' vocabulary retention has been widely used in the educational setting for many decades. The acquisition of vocabulary as part of the subskills of the English language is considered a vital part of learning any target language. Hence, this research study aimed at exploring the effects of using games to teach vocabulary in reading comprehension among freshmen students at Takhar University. This study has employed mixed-method research involving pre-test, post-test, and a semi-structured interview. The researcher employed descriptive statistical analysis to analyze the frequency and percentage of the respondents and inferential statistical analysis to mainly $\mathrm{T}$-test to figure out whether there is any significant difference in the mean score of the pre and post-test across gender. In addition, the inference method of the content analysis is also used for the semi-structured interview to identify whether games are motivating the students to enhance their vocabulary knowledge of the student. The targeted group was 20 freshmen students from the English department. The findings of the present study revealed that employing games are effective and beneficial for teaching vocabulary in reading comprehension. Moreover, the findings showed no significant difference in the mean score of the pre and post-test across gender. The study also indicated that games improved students' motivation in acquiring new vocabulary. Besides, it is hoped that educational games are more attractive, fun, and helpful in teaching and as well as building the vocabulary knowledge of the students. It is proposed that teachers should look for educational games and techniques to involve their students in the use of the creative expression in the enhancement of vocabulary knowledge.
\end{abstract}

\section{To cite this article:}

Hashemi, A. (2021). The Effects of Using Games on Teaching Vocabulary in Reading Comprehension: A Case of Gifted Students. Journal for the Education of Gifted Young Scientists, 9(2), 151-160. DOI: http://dx.doi.org/10.17478/jegys. 846480

\section{Introduction}

Reading comprehension is one of the key strategies of reading skills that allow students to make written texts meaningful (Hashemi and Kew, 2020). It is proposed that understanding through participation in written language is the process of creating and making sense. It is a system that allows students to make sense by communicating with the text. Reading comprehension is an essential component that involves students reading and understand a given text. It highly assesses the reading ability of learners and their aptitude to understand a text. Research has shown that students who lack vocabulary, will impede their comprehension of reading (Semtin and Maniam, 2015). This is because vocabulary teaching has always been a daunting activity for teachers and students, as vocabulary in the ESL classroom is given limited emphasis. Educational games are, therefore, one of the strategies in ESL classrooms to teach vocabulary. Educational games have been used in educational contexts for many decades (Pekalongan, et al. 2019). Therefore, employing educational games is hoped to be beneficial for students of the English department at Takhar University, Afghanistan.

In addition, Vocabulary Acquisition is regarded by students as one of the hardest components of learning the language. However, vocabulary is considered one of the sub-skills of the language (Orfan, 2020). Although, there is 
not much attention paid to making it simpler and easier for enhancing the vocabulary knowledge of the students. Moreover, vocabulary knowledge helps improve the social potential of the student and also in improving the communicative skills of the student. For students to develop their vocabulary skills, different ways and techniques can be helpful. But there are no clear rules that allow vocabulary to be learned by students. Every student has their way of building vocabulary knowledge. Various studies have shown that learning new vocabulary by using games has helped to increase vocabulary retaining and make language learning fun and inspiring (Hoa and Trang, 2020; Ma and Yodkamlue, 2019; Selvi and Çoşan, 2018).

However, using educational games for the enhancement of the vocabulary skills in the upper classes of the Afghan classroom is not given much consideration and attention. Furthermore, the acquisition of vocabulary in the Afghan context is more based on the traditional way. According to Orfan, et al. (2021), grammar translation method is considered as the dominant approach among Afghan university lecturers. The teachers are used to teach vocabulary by repeating its pronunciation and meaning several times and as well as requesting the students to follow the same rule to memorize the vocabularies. Following in the footsteps of prior studies on the use of educational games to teach vocabulary, the study was carried out to teach vocabulary in reading comprehension using educational games. This paper, therefore, targeted three topics to be explored in the Afghan context, which are educational games, reading comprehension, and motivation to figure out the effects of using games in teaching vocabulary and as well as to identify how educational games motivated the students to build their vocabulary knowledge. In this regard, the focus of our attention in the current study is to teach vocabulary through games, the encouragement of the student, and the impact of vocabulary on reading comprehension. Therefore, the current mixed-method research helps to find out the results of employing games in teaching vocabulary and motivation among Takhar University freshmen students to learn vocabulary.

\section{Literature Review}

The emphasis of every student and instructor has recently been on improving vocabulary awareness through games. Donmus (2010) suggested that games have significant value in enhancing the vocabulary skills of students in educational toys. Similarly, the results of a study by Barabadi and Khajavi, (2017) suggest that the combination of education and games can be both educational and entertaining. The world of the class can be made more communicative when learning vocabulary through games. Besides, Murray and Ian, (2018) accepted that engaging students in activities such as using games allows learners to more quickly recall new vocabulary. Game-based education helps the learning process to be fearless and meaningful. The acquisition of vocabulary by using games has encouraged students to contribute with each other and enhance the knowledge of their vocabulary (Ebrahimzadeh and Alavi, 2016). They are also supportive in keeping teachers to be boring and also helping them feel free to instruct students in an expressive way of learning.

In learning new vocabularies, games have plenty of advantages and effectiveness. For all students in the class, games will create a friendly atmosphere where every student is interested in a fun and competitive way of the supportive learning environment. In this way, in a group, the students will have the ability to assist each other to solve the issues posed when working together. They will also stimulate the imagination of students and develop their capability to practice the language entertainingly (Rasti-Behbahani and Shahbazi, 2020; Akramy, 2020). As can be seen, it can bring pleasure and motivate both teachers and learners to make the learning process significant and comprehensible by teaching vocabulary through games. In a language teaching classroom, it is not possible to disregard the essential role of games in educating and learning new vocabulary.

Learning vocabulary plays a vital role in reading comprehension. To understand the text as easily as possible, reading comprehension needs enough vocabulary awareness. The researchers claimed that reading skill as the main skill of the language and vocabulary skill as the sub-skill are interrelated with each other. Lack of vocabulary will affect learners' understanding of reading, and reading comprehension is considered a major necessity and vital factor (Hashemi and Kew, 2020). Ibrahim et al. (2016) recognized that there is a relation between vocabulary and reading comprehension as student concurrently develop their vocabulary knowledge. Thus, reading comprehension and vocabulary are the dependable elements that can make the learning process simple and understandable.

Rolletschek (2020) claimed that it was easier for those with a strong background in vocabulary knowledge to understand the text comparing to those who lack vocabulary knowledge. Moghadam et al. (2012) studied the vital role of vocabulary in reading comprehension in the Malaysian context, it was found that learning vocabulary is the primary goal of language learning, whether it is a second or a foreign language. Researchers accepted that vocabulary competence is the fundamental factor for skilled learners and suggested that those with excellent vocabulary 
knowledge would be effective in comprehending the reading text (Camacho \&Vásquez 2019; Ovalle et al. 2020; Kamnardsiri et al. 2017; Li \& Cummins, 2019; Miyazaki, 2019). Likewise, a study by Kameli \& Baki (2013) investigated the effect of the level of vocabulary awareness on EFL reading among Iranian students. They claimed that vocabulary awareness has an influence on reading comprehension at different levels of learners.

Several methods and techniques help students to enhance their vocabulary skills. Motivation, whether intrinsic or extrinsic motivation, is one of the main factors in enhancing the vocabulary knowledge of the students in reading comprehension (Franciosi et al. 2016). There are also several ways, however, to inspire learners to actively engage in learning and developing their knowledge of vocabulary. This objective can be accomplished by using games for the enhancement of the vocabulary knowledge of the students in the classroom. It is also distinguished that educational games can be inherently and extrinsically driven to provide an enjoyable atmosphere. This learning process can be over-learning and can inspire learners to learn and to promote the learning process for the teachers. (Bakhsh, 2016) thought that it offers a social function and social meaning to inspire students by using games in learning vocabulary. Student interpersonal skills and even verbal engagement in a cooperative manner with group learning.

\section{Definition of Reading Comprehension}

Reading uses receptive abilities and defines the language potential of a learner. Chung and Bidelman, (2021) described reading as the text implementing values from written documents. This desires the unity of the multifarious initiation of knowledge connected with it. Sowell (2018) strongly supports this view, explaining reading as a mechanism of conceiving meaning that includes the existing awareness of the reader, text content, and text reading. Meanwhile, Shimono (2018) claimed that reading is a mutual progression between readers and reading texts that result in a fluent reading of the text. In this regard, while reading readers can often communicate with the texts as they can derive the meaning by using different kinds of information, such as bottom-up processing and top-down processing. Dindar et al. (2021) also indicated that reading aims to obtain correct information from a reading background that the writer intended to attain from the reader. $\mathrm{Li}$ and Cummins (2019) argued that reading creativity can be described as an intellectual skill a person can use when engaging with the circumstance they are reading. Most importantly, reading is a cognitive and productive activity as the students need to connect written symbols and use his/her prior experience to understand and extract meaning from the sense of reading and the author's purpose. Reading, as a result, helps learners understand a text.

Comprehension refers to the process of acquiring and making meaning through communication and written language participation (Miyazaki, 2019). He described comprehension as the growth in the mind of the reader to design meaning by engaging with the context. Readers do this through the combination of their previous knowledge and experience, text details, and their views on the text. In the meantime, Chung and Bidelman (2021) claimed that understanding of reading refers to a growth in a text's context. The reader's primary objective is to obtain an interpretation of the text as opposed to knowing the meaning of sentences. Reading comprehension is thus a process of formulating language, recognizing, and responding to what is written in a particular text.

\section{Strategies of Reading Comprehension}

Besides, three styles help to explain reading: interactive, bottom-up, and top-down. The cognitive mechanism that occurs when readers interrelate with the text is clarified by these models. A decoding method and a set of written symbols into aural sounds is the principle of the bottom-up reading model (Barabadi and Khajavi, 2017). In other words, the emphasis of this method is first on letters, then on sentences followed by phrases in the text. According to this approach, the comprehension of the text is accomplished based on the number of details in each paragraph. The top-down model, however, is the opposite of the bottom-up one, since readers use their previous experience to refer to a new text in this top-down model. This method, therefore, starts by concentrating on larger aspects of the document, such as the title, basic points, and then focuses on reduced features of linguistics in the text. An interactive strategy of the reading model is the third model. This reading model refers to an example of reading that requires the concurrent involvement of both top-down and bottom-up procedures. As Pourhosein and Gilakjani (2016) claimed that sufficient reading entails processing both top-down and bottom-up. Teachers can look for guidance in reading based on this model to boost the abilities of L2 students.

In reading comprehension there are limited methods that play an important role: applying and stimulating context information, aggravating and asking questions, creating an inference, anticipating, epitomizing, visualizing, and tracking comprehension. One of the methods that help the reader's previous knowledge to better interpret a reading text is to stimulate and apply context knowledge. This understanding consists of the interactions of individuals with their principles of understanding how the written text works, including word recognition, print concepts, word sense, 
and how the text is created (Gilakjani, 2016). Another technique for reading comprehension is creating and answering questions. Readers would like to ask themselves some important questions to get a clearer understanding of the text they are reading. This approach allows readers to recognize the main concept and essential details in a text (Davenport et al. 2017). Making inferences is another approach to reading comprehension (Tarchi, 2015). In this method, readers need to infer from data in a text. The data from the text and their previous information will be combined.

Predicting is another skill of the reading techniques that help readers to guess by getting information about a text. To learn new information from the text, the readers use their prior knowledge. The content may be expected by readers based on the author and the title of the text. Davenport et al. (2017) once mentioned that for readers to remember the text they read quickly, encapsulating is a critical technique. By doing this, readers can incorporate all the data into a reading text and describe it using their own words. As readers use this approach, they can understand the text's structure, the text's emphasis, and the way opinions are connected. Effective narrative text summarization involves topics such as connecting events in a plot or recognizing basics that stimulate the activities and behavior of a character. As one of the techniques, visualizing helps readers to imagine to grasp a text. Readers who imagine when they read without any assistance, recall the content of the text and as well as help them remember some non-concrete points and significant names (Rasti-Behbahani and Shahbazi, 2020). Finally, monitoring is one of the successful techniques that enable readers to use acceptable and different strategies in various categories of manuscripts. Besides, it allows learners to make the best decision-maker, as they can select and use a suitable strategy when appropriate.

\section{Educational Games}

Vocabulary in the English language is considered to be one of the sub-skills of the four integrated skills (writing, reading, speaking, and listening). It is also recognized among learners as a hard part of language learning. There is also no clear and effective rule and method for helping students to learn the vocabularies and terminologies. More precisely, this study aims to figure out how to teach vocabulary using games, how to inspire students to learn vocabulary to enhance their ability to communicate, and how successful vocabulary in their academic contexts is to understand any reading text.

It is very fun to learn vocabulary through games and has garnered a lot of popularity among teachers and students. Sowell (2018) believed that because they support making language education enjoyable, the importance of educational games has increased in language education. He noted that it can be entertaining and educational when a game is selected as a medium for teaching and educating students to improve the classroom atmosphere. As Riahipour and Saba (2012) accepted that typical practices such as memorizing long lists of words, derivations, translation, word repetition, fill-in-the-blank exercises are all hard and repetitive to recall for students.

Similarly, the impact of games on the level of development of Iranian EFL vocabulary awareness among kindergarten students was investigated by (Aslanabadi and Rasouli 2013). Their aim of the research was to find out about every realistic and enjoyable way to learn vocabulary. To perform their study, the researchers covered two kindergartens. The researchers then split the students into two experimental and control groups. An online language teaching game is given to the experimental group and periodic class lectures are given to the second group, which is the control group. Their study results showed that game teaching not only retains the class alive and enjoyable but also helps learners to enhance their skills and trust in vocabulary. Besides, Hoa and Trang (2020) reported that those who use games in the classroom to teach new words to their students have fun and a pleasant environment rather than those who teach their students the traditional language.

Techniques are not commonly used to teach and practice vocabulary, such as using games. They are only used by both teachers and students for a time or occasion that can be powerless and useless. Learning vocabulary through games is helpful and has many advantages. Prabha and Abdul Aziz (2020) stressed that games should provide learners with a learning experience that is fun-filled and calming. Students can use language in a non-stressful way after studying and using new vocabulary. Although students learn vocabulary and their emphasis is on the message rather than the language. Therefore, the linguistic forms don't matter to them and they just feel free to preserve the theme. This would remove the fear of publicly assessing or evaluating students negatively and this may be the primary reason for students to reduce their anxiety and learn more in a friendly environment (Miyazaki, 2019).

\section{Research Questions}

- Is there any effect of using games on teaching vocabulary in reading comprehension?

- Is there any significant difference in the scores of pre and post-test across gender?

- How is the motivation of games in enhancing the vocabulary knowledge of the students in reading comprehension? 


\section{Method}

\section{The Design of the Research}

The study employed a mixed-method design, qualitative and quantitative (experimental research) to achieve a comprehensive understanding of the research topic. The qualitative data is obtained through the use of interviews and whereas the quantitative data comes from the pre and post-test. Descriptive and inferential statistical analysis is employed to analyze the data in the study. For the qualitative analysis, the researcher employed a semi-structured interview analysis through the content analysis method where certain themes have been inferences to be categorized. The qualitative approach is used to delve further into the minds of respondents and ask more open questions, and as well as it allows the researcher for more intense and accurate data to be collected (Daqiq and Hashemi, 2021).

\section{Participants}

The researcher employed convenience sampling and purposeful sampling techniques to choose the participants. Convenience sampling is a time constraint and easy to meet the students (Semry and Mahendran 2015). The present research also used purposeful sampling, which is also known as judgment sampling. Based on their results in the previous exam, the samples are selected (Ilker et al. 2015). From the same 20 participants selected earlier, 16 participants participating in the pre-and post-test, and 4 participants are chosen for the interview session.

\section{Data Collection Procedure}

The pre and post-test and as well as interview sessions are used as the methods for collecting the data in this study. Kelly (2019) indicates that the pre-test shows the degree of comprehension of a student before teaching, while a posttest assess the learning process of the students. Before and after the implementation of the action, the pre-test was conducted by using games as the experimental group where the students were expected to match the vocabulary with their meanings. While the control group was given the treatment as the traditional way of teaching. To show the progress and development in the performance of the students, the number of correct answers and percentages were used. In addition to the pre-and post-test methods, a semi-structured interview was used to assess how successful are games in motivating the students for the enhancement of their level of vocabulary knowledge in reading comprehension. Kallio et al. (2016) clarified that a semi-structured interview allows participants the ability to articulate their point of view. It boosts two-way contact in which the interviewer may ask questions about those being questioned.

\section{Materials and Instruments}

Before and after the implementation of the action, the pre and post-tests were carried out using five distinct games such as memory game, ladder, snake and bingo, Pictionary, and wheel of fortune where the students were expected to align the vocabulary with their meanings in the pre-test and the traditional method of teaching vocabulary was followed in the control group. None of the students managed to pick or fit all 10 terms to the correct meaning from the pre-test result. The lowermost percentage recorded by the students in the pre-test is 20 percent, where that individual student will correctly select or match 2 out of 10 words to their context.

\section{Data Analysis}

The analysis of the data was carried out through the Statistical Package of Social Science (SPSS) software, version 26. The descriptive statistical analysis was used to compute the frequency, percentage, and mean. Besides, the inferential statistics were employed to examine the differences of pre and post-test scores across gender and as well as for comparing the pre-test and post-test scores. Moreover, semi-structured interview sessions were conducted with four students, especially about how it helped them to develop their vocabulary knowledge by reading comprehension. The researcher analyzed the outcomes of the data obtained from the semi-structured interview through the content analysis method.

Table 1.

\section{Results}

Descriptive Statistics for Respondents' Age

\begin{tabular}{llcccc}
\hline Gender & & Frequency & Percent & Valid Percent & Cumulative Percent \\
\hline Valid & Male & 10 & 50.0 & 50.0 & 50.0 \\
& Female & 10 & 50.0 & 50.0 & 100.0 \\
& Total & 20 & 100.0 & 100.0 & \\
\hline
\end{tabular}

The participants of the present study were 20 Afghan university EFL students including male and female from freshmen class at Takhar University. There were equally 10 male participants and 10 female who participated in the study. 
Table 2.

Descriptive Statistics for Respondents' Gender

\begin{tabular}{lccccc}
\hline Age & & Frequency & Percent & Valid Percent & Cumulative Percent \\
\hline Valid & $18-20$ & 9 & 45.0 & 45.0 & 45.0 \\
& $20-23$ & 7 & 35.0 & 35.0 & 80.0 \\
& $23-25$ & 4 & 20.0 & 20.0 & 100.0 \\
& Total & 20 & 100.0 & 100.0 & \\
\hline
\end{tabular}

According to Table 2, the age of the respondents ranged from 18 to 25 where all the students at the undergraduate level fit between these ages. There were 9 respondents who had 18-20 years old and 7 respondents whose ages ranged between 20-23 years old. While 4 respondents had 23-25 years old.

\section{Pre-Post Test}

According to Table 3, students, S7, S9, and S13 recorded the same percentage in the pre-test, which is 20 percent. The lowest percentage scored by the students in the post-test is 70 percent, where that certain student will correctly choose or match 7 out of 10 words to their context. Only one student, S13, had a post-test score of $70 \%$. For posttest, the lowest percentage of the pre-test is 20 percent, while 70 percent indicates that the action works and is successful for students to develop reading comprehension vocabulary. As can be seen from the results, all the students in the post-test managed to select or fit more than 6 terms correctly to their meanings.

Table 3.

Descriptive Statistics of the Students Before and After the Implementation of Games

\begin{tabular}{|c|c|c|c|c|}
\hline Respondents & $\begin{array}{c}\text { Number of Correct } \\
\text { Answers }\end{array}$ & $\begin{array}{c}\text { Pre-Test Scores } \\
(100 \%)\end{array}$ & $\begin{array}{c}\text { Number of } \\
\text { Correct Answers }\end{array}$ & $\begin{array}{c}\text { Post-Test Scores } \\
(100 \%)\end{array}$ \\
\hline S1 & 4 & 40 & 9 & 90 \\
\hline S2 & 5 & 50 & 8 & 80 \\
\hline S3 & 5 & 50 & 10 & 100 \\
\hline S4 & 4 & 40 & 8 & 80 \\
\hline S5 & 3 & 30 & 9 & 90 \\
\hline S6 & 4 & 40 & 10 & 100 \\
\hline S7 & 2 & 20 & 8 & 80 \\
\hline S8 & 3 & 30 & 8 & 80 \\
\hline S9 & 2 & 20 & 8 & 80 \\
\hline S10 & 4 & 40 & 8 & 80 \\
\hline S11 & 3 & 30 & 8 & 80 \\
\hline S12 & 6 & 60 & 9 & 90 \\
\hline S13 & 2 & 20 & 7 & 70 \\
\hline S14 & 3 & 30 & 9 & 90 \\
\hline S15 & 3 & 30 & 8 & 80 \\
\hline S16 & 5 & 50 & 10 & 100 \\
\hline S17 & 3 & 30 & 8 & 80 \\
\hline S18 & 6 & 60 & 10 & 100 \\
\hline S19 & 3 & 30 & 8 & 80 \\
\hline S20 & 6 & 60 & 10 & 100 \\
\hline
\end{tabular}

This indicates that in reading comprehension, there was a great increase in the vocabulary skills of the students. In the pre-test, the highest percentage scored by the students is $60 \%$ where that specific student can correctly select or match 6 out of 10 terms to their meanings. In the pre-test, three students, S12, S18, and S20, scored $60 \%$. On the other side, where 5 students scored maximum marks, the highest percentage scored by the students in the post-test is 100 percent. These 5 students can correctly pick or fit 10 words to their meanings.

Table 4.

The Descriptive Statistics of Respondents

\begin{tabular}{llllclllll}
\hline & & $\mathrm{N}$ & Mean & Std.Deviation & Std.Error & Lower Upper & Minimum & Maximum \\
\hline Pretest & Male & 10 & 2.4000 & 1.34990 & .42687 & 1.4343 & 3.3657 & 1.00 & 5.00 \\
& Female & 10 & 3.7000 & 1.05935 & .33500 & 2.9422 & 4.4578 & 2.00 & 5.00 \\
& Total & 20 & 3.0500 & 1.35627 & .30327 & 2.4152 & 3.6848 & 1.00 & 5.00 \\
Posttest & Male & 10 & 8.2500 & .95015 & .30046 & 7.5703 & 8.9297 & 7.00 & 9.50 \\
& Female & 10 & 7.8000 & .91894 & .29059 & 7.1426 & 8.4574 & 7.00 & 10.00 \\
& Total & 20 & 8.0250 & .93857 & .20987 & 7.5857 & 8.4643 & 7.00 & 10.00 \\
\hline
\end{tabular}


Table 4, illustrates the mean differences between male and female respondents. As can be seen, the mean score of the male respondents was 2.4 in the pretest while the same respondents' mean scores have been dramatically changed to 8.25 in the post-test. Similarly, the mean score of the female respondents was 3.7 in the pretest while the mean score of the female respondents in the post-test was considered 7.8 .

Table 5.

The Significant Difference Between the Pre and Post-test

\begin{tabular}{lccccccccc}
\hline & F & Sig. & $\mathbf{t}$ & $\mathbf{d f}$ & $\mathbf{p}$ & Mean & Std. Error & Lower & Upper \\
\hline Pretest & .750 & .398 & -2.396 & 18 & .028 & -1.30000 & .54263 & -2.44002 & -.15998 \\
Posttest & .355 & .559 & 1.077 & 18 & .296 & .45000 & .41800 & -.42818 & 1.32818 \\
\hline
\end{tabular}

As can be seen in Table 5, the result of the T-test shows that the P-value for the pre-test was greater than the alpha level $\mathrm{p}=0.39>0.05$. Therefore, it can be concluded that there is no statistically significant difference in the pre-test scores between males and females. Similarly, concerning the post-test, the P-value based on Levene's Test for equality of variance is greater than the alpha level $\mathrm{p}=0.55>0.05$. Therefore, it can be also concluded that there is no statistically significant difference in the post-test scores across gender.

\section{Semi-Structured Interview}

The researcher decoded three themes that were motivation, the interest of students, and the features of games. These three themes allowed us to understand how games in reading comprehension helped students to develop their vocabulary. The emerging theme, first and foremost, was motivation. The students were motivated and get inspired through the use of games, and as well as able to understand the meaning of the words. The evidence from the interview showed that games increased the incentive of learners to develop vocabulary in reading comprehension. For example, when the answer was happy, happier, S15 felt proud. Similarly, S1 thought the same as well. The reaction was "happy." Next, it is indicated that games prompted the interest of learners to learn or understand the sense of vocabulary by playing games for the second subject. The proof can be seen in the reply from S11, who said, "Yes, it's easy." Finally, the theme extracted from the interview sessions was the games' characteristics.

Table 6.

Content Analysis of Student's Interview Sessions

\begin{tabular}{|c|c|c|c|}
\hline Themes & Keywords/Categories & Participants & Transcription \\
\hline \multirow[t]{4}{*}{ Motivation } & \multirow{2}{*}{ happy } & S1 & Happy \\
\hline & & S15 & happier \\
\hline & proud & S11 & I am proud \\
\hline & excited & S16 & I am excited \\
\hline \multirow{7}{*}{$\begin{array}{l}\text { Students' } \\
\text { Interest }\end{array}$} & Easy & S11 & Yes, it is easy \\
\hline & \multirow{2}{*}{ Helpful } & S11 & Yes, helpful \\
\hline & & S16 & Yes, helpful \\
\hline & interesting & S15 & Yes, interesting \\
\hline & understandable & S1 & Yes, I understand the words \\
\hline & \multirow{2}{*}{ Like } & S1 & Yes, I like it because can understand the words \\
\hline & & S15 & Yes, I like the games \\
\hline $\begin{array}{l}\text { Features of } \\
\text { The Games }\end{array}$ & Visual & S11 & Yes, I like it because it has pictures \\
\hline
\end{tabular}

It was clear that pictures served as guides to grasp the significance of words for students. Maryam (2012) supported this by stating that positive images helped to explain the textual content and encouraged learners to create bridges between verbal (text) and non-verbal (illustration).

\section{Discussion and Conclusion}

Concerning the first research question on whether there are any effects of using games on teaching vocabulary in reading comprehension or not. The findings of the study indicated that educational games have improved the vocabulary knowledge of the students. Their comprehension and understanding of the vocabulary have also been enhanced. The findings of the study are similar to the studies conducted by (Alhajaji et al. 2020; Camacho Vásquez and Ovalle, 2019; Karaaslan et al. 2018; Miyazaki, 2019) who indicated that educational games are the key factors to improve vocabulary knowledge. Before this, they felt it was hard to learn English, but when the use of educational games was introduced in the classroom, students felt more energetic and excited to join in in the lesson given to them. The findings of the study also show that a variety of educational games benefited students in learning and building 
new vocabularies and as well as help them to comprehend the reading text efficiently. This finding is in line with the findings of a study carried out by Allen et al. (2015) who believed that using proper games while teaching students can enhance their comprehension and as well as their ability to build their vocabulary knowledge. Students are always stressed that they and other students who don't focus in class should improve a little bit of their vocabulary knowledge. To ensure that all students engage in the lesson and learn new vocabulary through playing games, it would be better to strengthen their memory to be able to memorize it by just reading it the normal way.

Besides, the findings of the current study show that students are more likely to play educational games or a kind of language game that makes them feel interested in learning vocabulary knowledge. For children and adults, educational games have always been common and fun activities, it will be more interesting because students will focus on various activities to ensure the learning process is going well. Thus, this study indicated that educational games have motivated students to take part in each session of vocabulary learning. Hence, the findings of this study are consistent with these studies conducted by (Derakhshan and Davoodi Khatir, 2015; Ebrahimzadeh and Alavi, 2016) where they indicated that educational games motivated students and increased their participation in learning vocabulary. In this regard, it is for teachers to use language games to enhance the vocabulary knowledge of the students in reading comprehension, as the vocabulary provides a lot of value. In this respect, educational games are not going to delay the lesson but rather help the students to comprehend the reading text easily and effectively. Most importantly, the findings of the study show that educational games that were employed once should not be used again within a week, because they will feel bored and will not participate every day. This finding is confirmed by (Dindar et al. 2021) who focused on using games only once to teach the students. By using educational games, the students can improve their engagement, memorize new words, and as well as explain the new words.

Moreover, educational games have positive implications for learning and enhancing the vocabulary knowledge of the students. This is because students do not feel bored when learning these new words through educational games. The findings of this study are in line with the study conducted by Chen and Hsu (2020) where they have agreed on the effects of games in teaching vocabulary. Students can also be more excited when educational games are being used in the classroom and need to memorize the words they are learning immediately. In the sense of encouragement, educational games have a great influence on learners' vocabulary enhancement and memorization as well as on their psychological side in reading comprehension. This proved to be a successful way for both teachers and students to consolidate and use new lexical objects. As for the second research question on whether there is any significant difference in the mean scores of pre and post-test across gender. The findings of the study showed that there is no statistically significant difference in the pre and post-test scores of the respondents across gender.

Considering the third research question on how is the motivation of games in enhancing the vocabulary knowledge of the students in reading comprehension. The findings of the study in this respect indicate that motivation is a key factor for the enhancement of the vocabulary knowledge of the students in reading comprehension. This finding has been supported by (Elaish et al. 2019; Khalidiyah, 2017; Shahriarpour and Kafi, 2014) who believed that using games can motivate the students to improve their vocabulary knowledge. Vocabulary terms are not for a day's study, but the students need to practice them every day so that they can use the words and know how to use them. In other words, for a specific student, vocabulary is very important because it takes some time to acquire the skills to learn something new. In the classroom, we just need to concentrate and the students can apply the urge to learn something new. There will be a time when students will not take part in the lesson as they tend to be in their way, we as a teacher should know how to draw the attention of the students so that they can come and take part in the learning process. Since the students will be left out if the students do not participate, students will not be able to offer an example or clarify in their own words when it comes to explaining the meaning of the new words.

Considering that, vocabulary is a sub-skill of English language skill, especially for beginners who try their best to learn new words as much as possible, the instructor should use all his background to teach this skill in various ways. He or she needs to select a method that correctly collects all the factors that make it easier for them to understand. Several studies have agreed that language games, as a teaching tool, have a significant influence on improving the vocabulary of learners (knowledge, memorization, and use) as well as on their psychological side (motivation, relaxation, and self-confidence). The current research is carried out to illustrate the effects of using vocabulary through games in reading comprehension. In conclusion, learning vocabulary through games has been considered more effective in reading comprehension and will be more energetic for students who are willing to enhance their vocabulary knowledge in a strategic and fun way. On the other hand, employing games for teaching and learning vocabulary allow the students to participate more frequently. 
The goal of the current study was to examine the impact of using games on students' vocabulary knowledge in reading comprehension and to find out the efficacy of games in encouraging students to develop their vocabulary knowledge in reading comprehension. Therefore, the results of this study showed that the use of five different games in reading comprehension steadily increased the vocabulary skills of the students. In addition to that, without the help of facilitators, the students were able to understand and recall the words. This helped to inspire the students to learn the vocabulary when playing the games introduced during the class. Therefore, on the other hand, teachers have to take responsibility for attending to the needs of all students to maximize their vocabulary learning. It has also been shown that in reading comprehension, educational games have a significant influence on the vocabulary skills of students. In conclusion, the results of the current study have indicated that teaching vocabulary through educational games can increase the motivation of students as it provides them with enjoyable activities.

\section{Recommendations}

This paper has some recommendations for the use of educational games by students and teachers to enhance the vocabulary knowledge of the students. It is proposed that teachers should look for techniques to involve their students in the use of creative expression. Students may use the language more communicatively by using vocabulary games. Due to their benefits, educational games are widely recommended for both teachers and students to use in enhancing the vocabulary knowledge of the students. Because, they offer students accountability and the chance to be physically and mentally involved, and are student-centered rather than teacher-centered, easily attract the interest of children, promote their engagement, and are fun to play in the structured academic phase, and socialize students. Students often learn or grow several skills, such as taking turns, working independently, and working as a team with others for a common goal.

\section{The Limitations of the Research}

The present study is limited to several limitations number such as the number of participants was one constraint and less $\mathrm{N}=20$. Another limitation was, the researcher selected all the students from the same class (freshmen). Hence, the power of the study was lower than desired with the small number of participants $(\mathrm{N}=20)$. Moreover, this analysis was limited to one university whereas the large population from many universities could be more effective and generalizable. This university may not be representative of other universities, therefore, it restricts the generalizability of the results to other universities. Finally, it should be remembered that introducing more games into language classes to promote learning is a new strand of study. It is possible to consider the impact of learning concrete and abstract words through various games as another line of study. Mobile-assisted language learning apps can help learners develop their vocabulary domain, so the influence of various mobile applications on vocabulary learning is a good area of research to find out.

\section{References}

Akramy, S. A. (2020). Speaking anxiety in an Afghan EFL setting: A case study of an Afghan University. Language in India, 20(12), 161-182.

Aldana, \& L, I. (2020). The Effects of Review Games Using Kahoot! on Students' Quiz Scores. ERIC.Masters Thesis. (Vol. 21).

Alhajaji, B. H., Algmadi, J. S., \& Metwally, A. A. (2020). Exploring the success of GMT technique: Games, mind-mapping, and twitter hashtags in teaching vocabulary in EFL higher education environment. International Journal of Higher Education, 9(3), 290299. https://doi.org/10.5430/ijhe.v9n3p290

Allen, L. K., Snow, E. L., \& Mcnamara, D. S. (2015). Are You Reading My Mind ? Modeling Students' Reading Comprehension Skills with Natural Language Processing Techniques. https://doi.org/http://dx.doi.org/10.1145/2723576.2723617

Bakhsh, S. A. (2016). Using Games as a Tool in Teaching Vocabulary to Young Learners. English Language Teaching, 9(7), 120. https://doi.org/10.5539/elt.v9n7p120

Barabadi, E., \& Khajavi, Y. (2017). The effect of data-driven approach to teaching vocabulary on Iranian students' learning of English vocabulary. Cogent Education, 4(1). https://doi.org/10.1080/2331186X.2017.1283876

Camacho Vásquez, G., \& Ovalle, J. C. (2019). The Influence of Video Games on Vocabulary Acquisition in a Group of Students from the BA in English Teaching. GIST Education and Learning Research Journal, 19(19), 172-192.

Chung, W. L., \& Bidelman, G. M. (2021). Mandarin-speaking preschoolers' pitch discrimination, prosodic and phonological awareness, and their relation to receptive vocabulary and reading abilities. Reading and Writing, 34(2), 337-353. https://doi.org/10.1007/s11145-020-10075-9

Daqiq, B., \& Hashemi, A. (2021). Attitude of Afghan youths on watching foreign dubbed serials: A case study of Takhar University, Afghanistan. International Journal of Social Sciences and Education Research, 7(2), 173-180. https://doi.org/https://doi.org/10.24289/ijsser.874101

Davenport, C. A., Alber-Morgan, S. R., Clancy, S. M., \& Kranak, M. P. (2017). Effects of a picture racetrack game on the expressive vocabulary of deaf preschoolers. Journal of Deaf Studies and Deaf Education, 22(3), 326-335. 
https://doi.org/10.1093/deafed/enx015

Derakhshan, A., \& Davoodi Khatir, E. (2015). The Effects of Using Games on English Vocabulary Learning. Journal of Applied Linguistics and Language Research, 2(3), 39-47. Retrieved from www.jallr.ir

Dindar, M., Ren, L., \& Järvenoja, H. (2021). An experimental study on the effects of gamified cooperation and competition on English vocabulary learning. British Journal of Educational Technology, 52(1), 142-159. https://doi.org/10.1111/bjet.12977

Ebrahimzadeh, M., \& Alavi, S. (2016). Motivating EFL students: E-learning enjoyment as a predictor of vocabulary learning through digital video games. Cogent Education, 3(1). https://doi.org/10.1080/2331186X.2016.1255400

Elaish, M. M., Ghani, N. A., Shuib, L., \& Al-Haiqi, A. (2019). Development of a Mobile Game Application to Boost Students' Motivation in Learning English Vocabulary. IEEE Access, 7, 13326-13337. https://doi.org/10.1109/ACCESS.2019.2891504

Franciosi, S. J., Yagi, J., Tomoshige, Y., \& Ye, S. (2016). The effect of a simple simulation game on long-term vocabulary retention. CALICO Journal, 33(3), 355-379. https://doi.org/10.1558/cj.v33i2.26063

Hashemi, Aminuddin Kew, S. N. (2020). The Effects of Using Blended Learning in Teaching and Learning English : A Review of Literature. The Eurasia Proceedings of Educational \& Social Sciences (EPESS), 18(4), 173-179.

Hashemi, A., \& Kew, S. N. (2021). A critical discourse analysis of a news report on two mosques shooting in Christchurch-New Zealand. International Journal of Social Sciences and Education Research, 7(4), 15-24. https://doi.org/10.24289/ijsser.838397

Hashemi, A. (2021). Effects of COVID-19 on the academic performance of Afghan students' and their level of satisfaction with online teaching. Cogent Arts and Humanities, 8(1). https://doi.org/10.1080/23311983.2021.1933684

Hoa, T. M., \& Trang, T. T. T. (2020). Effect of the Interactive Whiteboard on Vocabulary Achievement, Vocabulary Retention and Learning Attitudes. Anatolian Journal of Education, 5(2), 173-186. https://doi.org/10.29333/aje.2020.5215a

Ibrahim, E. H. E., Sarudin, I., \& Muhamad, A. J. (2016). The Relationship between Vocabulary Size and Reading Comprehension of ESL Learners. English Language Teaching, 9(2), 116. https://doi.org/10.5539/elt.v9n2p116

Kallio, H., Pietil, A., Johnson, M., \& Kangasniemi, M. (2016). Systematic methodological review : developing a framework for a qualitative semi-structured interview guide. Journal of Advanced Nursing (JAN), $72(12), \quad 29-54$. https://doi.org/10.1111/jan.13031

Kamnardsiri, T., Hongsit, L. O., Khuwuthyakorn, P., \& Wongta, N. (2017). The effectiveness of the game-based learning system for the improvement of American Sign Language using kinect. Electronic Journal of E-Learning, 15(4), $283-296$.

Karaaslan, H., Kilic, N., Guven-Yalcin, G., \& Gullu, A. (2018). Students' Reflections On Vocabulary Learning Through Synchronous And Asynchronous. Turkish Online Journal of Distance Education-TOJDE July, 19(3), 53-70.

Khalidiyah, H. (2017). The use of domino game with picture in improving students 'vocabulary knowledge. Education and Language International Conference Proceedings Center for International Language Development of Unissula, 1(1), 349-358.

Li, J., \& Cummins, J. (2019). Effect of using texting on vocabulary instruction for English learners. Language Learning and Technology, 23(2), 43-64.

Ma, X., \& Yodkamlue, B. (2019). The effects of using a self-developed mobile app on vocabulary learning and retention among EFL learners. Pasaa, 58(December), 166-205.

Miyazaki, K. (2019). The Effect of an Online Vocabulary Learning Tool on Passive and Active Vocabulary Use at a Range of Proficiency Levels. Journal of Pan-Pacific Association of Applied Linguistics, 23(1), 85-108. https://doi.org/10.25256/paal.23.2.5

Murray, \& Ian. (2018). Use Of Multimedia Games For Biology Vocabulary Instruction (Vol. 15). Retrieved from http://awsassets.wwfnz.panda.org/downloads/earth_summit_2012_v3.pdf\%0Ahttp:

Noori, A.Q., Said, H., Mohamad Nor, F., \& Abd Ghani, F. (2020). The Relationship between University Lecturers' Behaviour and Students' Motivation. Universal Journal of Educational Research, 8(11C), 15 - 22. DOI: 10.13189/ujer.2020.082303.

Orfan, S. N. (2020). Afghan undergraduate students' attitudes towards learning English. Cogent Arts and Humanities, 7(1). https://doi.org/10.1080/23311983.2020.1723831

Orfan, S. N., Noori, A. Q., Hashemi, A., \& Akramy, S. A. (2021). Afghan EFL Instructors' Use of Teaching Methods. International Journal of English Language Studies (IJELS), 3(5), 31-38. https://doi.org/10.32996/ijels

Pekalongan, I., Rahmah, R. E., \& Pekalongan, I. (2019). The Use of Codenames Game to Help Students in Learning Vocabulary. Journal For Language And Foreign Language Learning, 8(2), 1-16. https://doi.org/http://dx.doi.org/10.21580/vjv8i23770 The

Prabha, T., \& Abdul Aziz, A. (2020). Effectiveness of Using Poly Category Mind Map for Vocabulary Development. Arab World English Journal, 11(2), 214-231. https://doi.org/10.24093/awej/vol11no2.15

Rasti-Behbahani, A., \& Shahbazi, M. (2020). Investigating the effectiveness of a digital game-based task on the acquisition of word knowledge. Computer Assisted Language Learning, O(0), 1-25. https://doi.org/10.1080/09588221.2020.1846567

Rolletschek, H. (2020). The Effects of Odor on Vocabulary Learning. Language Teaching Research Quarterly, 18, 21-39. https://doi.org/10.32038/ltrq.2020.18.02

Selvi, M., \& Çoşan, A. Ö. (2018). The effect of using educational games in teaching kingdoms of living things. Universal Journal of Educational Research, 6(9), 2019-2028. https://doi.org/10.13189/ujer.2018.060921

Semtin, S. A., \& Maniam, M. (2015). Reading Strategies among ESL Malaysian Secondary School Students. International Journal of Evaluation and Research in Education (IJERE), 4(2), 54. https://doi.org/10.11591/ijere.v4i2.4492

Shahriarpour, N., \& Kafi, Z. (2014). On the Effect of Playing Digital Games on Iranian Intermediate EFL Learners' Motivation toward Learning English Vocabularies. Procedia - Social and Behavioral Sciences, 98, $1738-1743$. https://doi.org/10.1016/j.sbspro.2014.03.601

Shimono, T. (2018). L2 Reading Fluency Progression Using Timed Reading and Repeated Oral Reading. Reading in a Foreign Language, 30(1), 152-179.

Sowell, J. (2018). Talking about Words: A Vocabulary Description Game. In English Teaching Forum.

Tarchi, C. (2015). Fostering reading comprehension of expository texts through the activation of readers ' prior knowledge and inference-making skills. International Journal of Educational Research, 72, 80-88. https://doi.org/10.1016/j.ijer.2015.04.013 